\title{
Tinnitus Disability Compensation: Focusing on Tinnitus Disorder Caused by Military Noise in Veterans
}

\author{
KyooSang Kim \\ Occupational Environmental Medicine, Seoul Medical Center, Seoul, Korea
}

\author{
이명의 요양과 장애 보상: 전역 군인의 군 소음으로 인한 이명 장애를 중심으로 \\ 김 규 상 \\ 서울의료원 직업환경의학과
}

\begin{abstract}
Military service personnel are constantly exposed to sudden, loud noises, and often show a higher auditory threshold than the general population, as well as tinnitus. Tinnitus in military personnel can occur alone, without any complaints of hearing impairment. When accompanied by hearing impairment, the low/mid-frequency hearing loss is not large, and the hearing threshold may appear to be increased in the high frequency range from 3-6 kHz. Therefore, by calculating the average hearing threshold and restricting disability assessments to cases of tinnitus with a moderate degree of hearing impairment of $50 \mathrm{~dB}$, most veterans with tinnitus will be excluded from compensation. Not only are the diagnoses, evaluations, and auditory complications of tinnitus not considered, neither are the mental and psychological effects, nor the aspects of treatment and rehabilitation related to quality of life. This study aims to examine the characteristics of tinnitus disorder due to military noise. In addition, this study proposes that tinnitus should be classified as a public occupational disease in veterans, and discusses problems with the criteria for disability compensation and examinations.
\end{abstract}

Key Words: Tinnitus, Military, Noise, Hearing impairment, Disability.

Received: May 2, 2017 / Revised: May 11, 2017 / Accepted: May 17, 2017

Correspondence: KyooSang Kim, Occupational Environmental Medicine, Seoul Medical Center, 156 Sinnae-ro, Jungnang-gu, Seoul 02053, Korea

Tel: +82-2-2276-7755 / Fax: +82-2-2276-7438 / E-mail: kyoosang@daum.net

\section{INTRODUCTION}

이명은 외부의 음원으로부터의 자극 없이 소리를 느끼는 상 태, 혹은 신체 내부에서 들리는 원하지 않는 청각적 자극이다. 이명은 실제 소리가 나지 않음에도 불구하고 소리가 들리는 것 을 호소하는 일종의 증상이다. 이명은 난청, 현기증과 더불어 중요한 청각 증상의 하나이다. 산업의 발달로 인한 소음 증가, 노령화 추세, 복잡한 생활과 약물남용 등 이명의 유발인자는 증 가하는 추세에 있다. 이명은 생명에 위협적이거나 다른 질병을 유발하는 위험한 장애는 아니지만, 이명으로 인해 나타나는 집 중력 장애, 수면장애, 불안 및 우울증 등과 같은 복잡한 현상들 이 이명 환자의 삶의 질에 부정적인 영향을 가져온다(Erlandsson et al., 1991; Tyler \& Baker, 1983). 이명은 개인의 청력장애
를 포함한 신체적 장애와 더불어 감정, 삶의 형태 등과 같은 일 상생활 전반에 걸쳐 장애를 초래하는 다면적인 현상으로, 이명 자의 $0.5 \sim 1 \%$ 는 일상생활을 하는 데에 심각한 지장을 받는다 (Erlandsson \& Hallberg, 2000).

군 복무자는 충격소음에 상시 노출되므로 동일 연령의 소음 비노출 일반 인구집단에 비해 높은 청력역치를 보인다(Humes et al., 2006). 군 경력과 관련한 청력손실의 특성은 음향외상성 난청이 많고, 초기에 고음역(특히 $6 \sim 8 \mathrm{kHz})$ 에서 청력손실이 크 고, 좌우 청력이 불일치하며, 와우와 중추청신경로에 영향을 미 치는 감각신경성 난청으로서 평균 청력역치의 평가에 따르면 초 기의 경도 난청을 보이고, 이명을 동반하는 경우가 많으며, 군 병과와 밀접하게 관련이 있다(Kim \& Chung, 2003). 이명을 호 소하는 군 전역자들의 대부분은 군 복무 중 충격소음에 노출되 
어 갑자기 이명이 발생하며, 난청을 동반한 경우가 많다(Kim et al., 2012a).

이명은 그 주관적인 특성으로 인해 환자의 보고를 완전히 제 외하고 객관적으로 증명하는 방법이 없으며, 이로 인해 이명 장 해의 정도를 평가하거나 배·보상 등 법률적 문제가 있을 때 환 자가 겪는 피해를 인정받기에 어려움이 있다. 비록 객관적인 증 명에는 한계가 있으나, 이명의 성상을 평가하는 이명도 검사와, 이명과 관련된 병력과 이명의 주관적 성상을 알아보는 시각 아 날로그 척도(Visual Analogue Scale) 등을 포함하여 이명이 삶 에 미치는 영향을 알아보는 이명 설문지가 개발되어 있다. 이와 같은 검사도구로 Hallam(1996)이 개발한 Tinnitus Questionnaire (TQ)와 Newman et al.(1996)에 의한 Tinnitus Handicap Inventory (THI), 그리고 Kuk et al.(1990)이 개발한 Tinnitus Handicap Questionnaire (THQ), Tinnitus Reaction Questionnaire (TRQ) 등이 있다. 이 중 THI는 이명에 대한 연구 목적으 로 가장 많이 사용되는 설문지로, 1996년 Newman et al.에 의 해 개발되었으며, 한국어 번역본에 대한 신뢰도와 타당도 연구 가 이루어져 있다(Kim et al., 2002; Newman et al., 1996).

미국은 전역 군인의 일반적인 복무 관련 장애에서 이명과 난 청이 1,2 위로 $15 \%$ 이상의 점유비를 보이고 있으며, 호주는 전 역군인 장애 신청 질환에서 난청과 이명 2,3 위를 점하고, 캐나 다의 참전용사의 지급 승인된 장애인 연금 질환에서도 이명과 난청이 1,2 위로 상위 빈도를 보이고 있으나, 우리나라는 군 복 무 중 발생하는 10 대 다빈도 질환에도 포함되어 있지 못하다. 그러나 우리나라의 사례 연구 결과에 의해서도 사격훈련 등으로 인한 난청과 이명 피해 사실이 실증적으로 확인되었고(Moon, 2007; Moon et al., 2008), 최근 군 전역자의 이명에 대한 연구 의 경우도 설문조사에 기반한 단면 연구이지만 이명으로 인한 여러 건강 영향과 우울증 및 낮은 건강수준을 보고하였다(Kim et al., 2012b; Lee et al., 2014).

군 복무 중 생긴 이명 피해로 전역 후 고통받는 전역자들의 국가유공자 신청이 해마다 늘고 있지만 인정 비율은 지극히 낮 아 집단 민원과 소송으로 이어지는 등 적극적인 구제방안 마련 이 요구되고 있다. 2012년 국가인권위에서는 군 전역자들의 '이 명피해'에 대한 전반적인 실태 조사를 권고하였고(2012.9.11), 국 회에서 군 전역자들의 ‘이명피해’에 대해 실효적 치료 보상을 위 한 입증책임(요건)과 상이등급 판정기준을 완화하고, 이명에 부 합하는 청력검사방법을 마련하도록 요구하였다.

이 연구는 군 소음으로 인한 이명 장애의 특성을 살펴보고, 특히 전역 군인의 이명에 대한 공무상 질병 인정 및 장해 보상 의 기준 적용과 심사에 따르는 제반 문제에 대해 고찰하고 제 언하고자 한다.

\section{REVIEW OF TINNITUS DISABILITY COMPENSATION}

\section{군 소음과 이명}

군 환경에서의 소음의 종류는 육군, 공군, 해군 등의 군대의 특성에 따라 다양하다. 그러나 명백히 귀에 영향을 끼치는 소 음의 근원은 무기, 제트기 엔진, 탱크 등이지만 군대의 차량, 비 행기, 선박 등에서 발생하는 소음 또한 잠재적인 소음성 난청 을 유발할 수 있는 원인이 될 수 있다(Humes et al., 2006). 군 환경에서 발생하는 소음의 경우, 소음의 종류로부터의 거리, 혹 은 조건 등에 따라 소음의 노출 수준이 변화하므로 일정하게 수치화하기는 어렵다. 총소리는 강렬한 충격음으로 작용한다. 단발 사격의 음압은 무기 종류에 따라 크게는 165 190 dB에 달한다(Salmivalli, 1978). U.S. Army Center for Health Promotion and Preventive Medicine(2004)의 보고에 따르면, 총소 리의 경우 모델에 따라 다양하지만 충격음은 약 $153 \mathrm{~dB}(\mathrm{~A})$ 에서 최고 $190 \mathrm{~dB}(\mathrm{~A})$ 이었다. 군 차량의 소음은 약 78 100 dB(A)이 었으며 헬리콥터의 소음은 101 106 dB(A) 수준이었다.

군에서 노출되는 소음은 연속적으로 노출되기보다 총/포 등 의 충격음에 단속적으로 노출되지만, 그 강도는 단 1 회의 노출 로도 음향외상으로 작용할 $140 \mathrm{~dB}($ Odess, 1972; Savolainen \& Lehtomäki, 1997; Ylikoski, 1989)을 초과하며, 군 복무기간 중의 지속적인 소음 노출로도 청력에 영향을 미친다. 또한 총/ 포의 충격음은 난청뿐만 아니라 이명과 전정기능의 장애로도 영향을 미친다(Ylikoski \& Ylikoski, 1994; Ylikoski et al., 1988). 소음이 내이의 유모세포에 영향을 미쳐 나타나는 감각신 경성 난청은 초기에 고음역의 청력손실을 특징적으로 보여주며, 군 충격소음은 음향외상으로 이명을 동반하고 초기에 경도 난 청을 보인다. 청각도상 고음점경형의 감각신경성 난청은 4 6 $\mathrm{kHz}$ 에서 전형적인 역치 상승을 보이며, 이 고음역에서의 음조를 갖는 이명도 특성을 보인다(Axelsson \& Ringdahl, 1989; Xu et al., 2011).

이명을 호소하는 군 전역자들의 대부분은 군 복무 중 충격 소음에 노출되어 이명이 발생하였으며, 난청을 동반한 경우가 대부분이다(Kim et al., 2012a). 그러나 정상 청력에서도 이명은 발생할 수 있으며, 정상 청력에서 이명이 발생하는 비율은 약 8 $12.5 \%$ 정도이다(Barnea et al., 1990; Samarei \& Fatholahi, 2014; Sanchez et al., 2005). 소음에 노출되면 일시적 또는 영 구적인 청력손상을 유발할 수 있다. 소음 노출 후 역치 회복은 내이의 감각 신경 구조에 대한 기계적 손상의 역전(reversal)을 나타내며, 청각 기능에 대한 지속적 또는 지연된 결과가 없음 을 나타내는 것으로 가정하고 있다. 그러나 난청이 발생하지 않 아도 내유모세포의 구심경로 차단으로 인하여 이명이 발생할 
수 있다. 즉, 가역적인 청력역치 상승을 일으키는 음향 과다 노 출은 와우 유모세포를 손상시키지 않지만 구심성 신경 말단의 급성 손실과 청신경의 퇴행성 변화를 야기한다. 이와 같은 결과 는 소음에 의한 손상이 기존의 청력검사 결과에서 드러난 것보 다 훨씬 더 광범위하게 진행됨을 시사한다. 이러한 일차 신경학 적 변성은 시끄러운 환경에서 청력에 어려움을 더해 줄 뿐만 아 니라 이명, 청각과민증 및 내이 손상과 관련된 기타 지각 이상 에 영향을 줄 수 있다(Kujawa \& Liberman, 2009). 그러나 이처 럼 강한 충격음이 내이 외유모세포의 손실이나 역치 상승을 일 으키지 않고 내유모세포와 청신경섬유 사이의 시냅스를 파괴 (cochlear synaptopathy)할 수 있지만, 이는 동물실험에서뿐만 이 아니라 인간에서 더 규명되어야 할 필요가 있다(Guest et al., 2017).

최근의 연구에서는 일반적으로 실시하는 청력검사(0.25 8 $\mathrm{kHz}$ )에서 청력손실이 $25 \mathrm{~dB}$ 미만이고 양이의 차이가 $10 \mathrm{~dB}$ 이내인 이명자 중 $2 / 3$ 에서, 연령과 성을 짝짓기한 정상군보다 8 $\mathrm{kHz}$ 이상 고음역 $(10,12,14,16 \mathrm{kHz})$ 의 청력역치가 유의하게 높 음을 보여 초고주파(ultra-high frequency) 음역의 청력손실이 이명의 원인이 될 수 있음을 시사하였다(Shim et al., 2009).

\section{공무상/직무상/업무상 질병}

공무상 질병은 공무원연금법, 군인연금법, 국가유공자 등 예 우 및 지원에 관한 법률 등에서, 직무상 질병은 사립학교 교직 원연금법, 선원법 등에서, 업무상 질병은 산업재해보상보험법에 서 다루고 있다. 이러한 질병의 범위에 관하여는 근로기준법 시 행령 제 44 조(업무상 질병의 범위 등)의 규정을 준용하고 있으 며, 구체적으로 각 법에서 질병의 인정기준을 제시하고 있다.

공무상 질병은 공무원연금법 시행령 제 29 조(공무상 질병 또 는 부상의 인정기준)에 1. 공무상 질병으로 가. 공무수행 과정 에서 물리적·화학적·생물학적 요인 또는 신체적·정신적 부담 을 주는 업무 등의 원인에 의하여 발생한 질병, 나. 공무상 부상 이 원인이 되어 발생한 질병, 다. 그 밖에 공무수행과 관련하여 발생한 질병으로 하고 구체적인 인정기준에 공무수행 장소의 강렬한 소음으로 인한 질병을 들고 있다[(별표 2의2) 공무상 질 병 또는 부상의 구체적인 인정기준(제29조제2항 관련)]. 타 법에 서 공무상 질병이나 직무상 질병 또한 유사하나 산업재해보상 보험법에서의 업무상 질병과 비교하면 질병의 범위와 구체성 측 면에서 보완할 필요가 있다.

산업재해보상보험법에서의 업무상 질병은 제 37 조(업무상 재 해의 인정기준)에서 업무와 재해 사이에 상당인과관계가 있어 야 하며, 가. 업무수행 과정에서 물리적 인자, 화학물질, 분진, 병원체, 신체에 부담을 주는 업무 등 근로자의 건강에 장해를 일으킬 수 있는 요인을 취급하거나 그에 노출되어 발생한 질병,
나. 업무상 부상이 원인이 되어 발생한 질병, 다. 그 밖에 업무와 관련하여 발생한 질병으로, 동법 시행령 제34조(업무상 질병의 인정기준)에서 (1) 근로자가 「근로기준법 시행령」 제44조제1항 및 같은 법 시행령 별표 5 의 업무상 질병의 범위에 속하는 질병 에 걸린 경우 다음 각 호의 요건 모두에 해당하면 법 제37조제 1 항제 2 호가목에 따른 업무상 질병으로 본다. 1. 근로자가 업무 수행 과정에서 유해·위험요인을 취급하거나 유해·위험요인에 노출된 경력이 있을 것, 2. 유해·위험요인을 취급하거나 유해· 위험요인에 노출되는 업무시간, 그 업무에 종사한 기간 및 업무 환경 등에 비추어 볼 때 근로자의 질병을 유발할 수 있다고 인 정될 것, 3. 근로자가 유해·위험요인에 노출되거나 유해· 위험요 인을 취급한 것이 원인이 되어 그 질병이 발생하였다고 의학적 으로 인정될 것. (2) 업무상 부상을 입은 근로자에게 발생한 질 병이 다음 각 호의 요건 모두에 해당하면 법 제 37 조제 1 항제 2 호 나목에 따른 업무상 질병으로 본다. 1. 업무상 부상과 질병 사 이의 인과관계가 의학적으로 인정될 것, 2. 기초질환 또는 기존 질병이 자연발생적으로 나타난 증상이 아닐 것, (3) 제 1 항 및 제 2 항에 따른 업무상 질병(진폐증은 제외한다)에 대한 구체적인 인 정기준은 별표 3과 같다. (4) 공단은 근로자의 업무상 질병 또는 업무상 질병에 따른 사망의 인정 여부를 판정할 때에는 그 근로 자의 성별, 연령, 건강 정도 및 체질 등을 고려하여야 한다.

업무상 질병의 보험급여는 요양급여, 휴업급여, 장해급여, 간 병급여, 유족급여, 상병보상연금, 장의비, 직업재활급여로 구성 되며, 4 일 이상의 요양을 요하는 경우의 요양급여는 진찰 및 검 사, 약제 또는 진료재료와 의지, 그 밖의 보조기의 지급, 처치. 수술·그 밖의 치료, 재활치료, 입원, 간호 및 간병, 이송 등으로 구성된다.

\section{소음성 난청과 이명의 인정 및 판정기준 검토}

직업병으로서 소음성 난청은 업무상/공무상/직무상 질병 관 련 법에서 그 기준이 상이하다. 산업안전보건법에서는 $4 \mathrm{kHz}$ 에 서 $50 \mathrm{~dB}$ 이상의 청력손실이 있고 3 분법상 청력손실 정도가 30 $\mathrm{dB}$ 이상(소음성 난청 유소견자 $\mathrm{D1}$ ), 산업재해보상보험법에서는 6 분법상 한 귀의 청력손실이 $40 \mathrm{~dB}$ 이상 $70 \mathrm{~dB}$ 미만(최저 제14 급제1호) [산업재해보상보험법 시행규칙(별표 5) 신체부위별 장 해등급 판정에 관한 세부기준(제48조 관련, 개정 2016.3.28.)], 군인연금법에서는 6 급법상 한 귀의 청력손실이 $90 \mathrm{~dB}$ 이상이 고 다른 한 귀의 청력손실이 $50 \mathrm{~dB}$ 이상(최저 제7급) [군인연금 법 시행규칙(별표 2), 신체부위별 상이등급 결정기준(제4조의8 관련, 신설 2014.12.31.)], 공무원연금법에서는 6분법상 한 귀의 청력손실이 $40 \mathrm{~dB}$ 이상, 다른 한 귀의 청력손실은 정상(최저 14 급제 3 호) [(공무원연금법 시행규칙(별표 1$)$, 신체부위별 장애등 급 판정기준(제23조 관련, 개정 2012.3.9.)], 국가유공자 등 예우 
및 지원에 관한 법률에서는 6 분법상 한 귀의 청력손실이 $80 \mathrm{~dB}$ 이상(7급 2107), 두 귀의 청력손실이 각각 $40 \mathrm{~dB}$ 이상(7급 2106)으로 규정되어 있다[국가유공자법 시행규칙(별표 4) 신체 부위별 상이등급 결정(제8조의3 관련), 개정 2016.2.29.]. 물론 산업안전보건법에서 난청의 기준은 요양/장해보상의 기준이 아 닌 소음성 난청의 예방을 위한 판정기준으로서 기능을 하기 때 문에 낮으나, 공무원연금법, 군인연금법 및 국가유공자 관련 법 의 공무상 질병으로서 난청은 발생의 사유가 대부분 공무 수 행 장소에서의 강렬한 소음으로 인한 질병이기 때문에 공무상 질병의 기준은 산업재해보상보험법과 같은 인정기준이 바람직 하나 장애인복지법의 6 분법상 한 귀의 청력을 $80 \mathrm{~dB}$ 이상 잃 고, 다른 귀의 청력을 $40 \mathrm{~dB}$ 이상 잃은 사람의 최저 등급(제6 급) [장애인복지법 시행규칙 (별표 1) 장애인의 장애등급표(제2 조 관련), 개정 2015.8.3.]에 기초하여 일반적으로 높다. 물론 최 근에는 청력손실의 평가방법이 4 분법에서 6 분법으로 바뀌고(국 가유공자법, 개정 2012.1.30.) 평가등급 체계의 개선이 이루어지 고 있다. 또한 관련 법에 따라 장해등급상 일시금 지급과 연금 지급에 따라 장해등급의 세분화 기준이 다른 측면이 있다. 즉, 산업재해보상보험법에서 장해보상연금 지급은 제7급부터 가능 하도록 되어 있다.

이명의 요양과 장해보상에 대해 산업재해보상보험법에서는 난청이 있고 뚜렷한 이명이 항상 있으며 그 증상이 타각적 검사 로 증명되는 경우 제 12 급 인정, 국가유공자법에서는 3 회의 이명 검사에서 모두 이명이 있고, 최소한 한쪽 귀의 청력장애가 50 $\mathrm{dB}$ 이상의 난청을 동반할 경우 제7급(2107) 인정, 장애인복지 법에서는 심한 이명(2회 이상 반복검사)이 있으며, 양측의 청력 손실이 각각 40 60 dB 미만인 경우 제6급으로 판정, 심한 이 명이 있으며, 청력장애 정도가 6 급인 경우 제5급으로 하고 있 다. 단, 심한 이명은 1 년 이상의 지속적이고 적극적인 진단과 치 료에도 불구하고 잔존 증상이 남아 있는 경우에 한하여 진료 기록지를 확인하여 판정하며, 진료기록지에는 이명에 대한 반 복적인 검사 기록이 있어야 한다.

전역 군인의 난청과 이명은 산업재해보상보험법의 적용을 받 는 근로자의 난청 또는 이명과는 다르다. 소음성 난청은 일반적 인 회화역의 평균역치 산정에 의한 3,4 분법보다 난청에 의한 의 사소통 장애가 크며, 순음 평균청력역치보다 어음청력역치가 큰 편이다. 따라서 청력을 평가하는 방법으로 평균청력역치 산정방 법에 고음역 $(4 \mathrm{kHz})$ 을 포함하는 4분법/6분법의 평가방법이나 어음청력평가 방법을 고려할 수 있다. 소음으로 인한 소음성 난 청은 일반 난청과 달리 고음역의 청력손실의 특성을 보인다. 더 구나 군의 충격소음은 일반적인 소음보다 고음역 $(4 \sim 8 \mathrm{kHz})$ 의 역 치손실에 큰 영향을 미친다. 그리고 소음성 난청은 비가역적인 감 각신경성 난청으로, 의사소통장애로서 중등도 난청 기준인 40
$\mathrm{dB} \mathrm{HL}$ 을 최소 장해기준으로 보는 것이 타당성이 있다. 이는 장 애인복지법의 비직업적인 청각장애의 장애등급 기준(6급) 체계 와는 다른 산업재해보상보험법의 업무상 질병으로서 직업적 청 력장해 장해등급 기준(14급)을 참고할 수 있다. 즉, 장애 정도에 따른 보상에 대한 좀 더 세분화된 접근이 필요하다.

이명은 국가보훈처(국가유공자법)나 고용노동부(산업재해보 상보험법) 모두 난청이 있고 뚜렷한(현저한) 이명이 항상 있는 경우 그 증상이 타각적 검사로 증명되는(입증 가능한) 것으로 되어 있다. 그러나 이명은 주관적인 자각증상이므로 이명의 주 파수와 크기를 검사(이명도 검사, tinnitogram)함으로써 객관적 인 수치로 표현하는 정량적 검사보다는 이명의 발생과 불편 정 도에 대한 심리적 혹은 사회적 요인과 관련한 심리평가가 중요 하다. 이와 관련하여 대표적인 것으로 이명장애지수(THI)를 들 수 있다. 그리고 소음으로 인한 이명은 난청을 동반하는 경우가 일반적이지만, 난청을 동반하지 않는 경우도 많으며, 또한 이때의 난청에 최소 청력장애기준인 $50 \mathrm{~dB}$ 을 적용하는 것은 무리가 있 다. 난청의 기준을 적용한다면 소음으로 인한 고음역 $(3 \sim 6 \mathrm{kHz})$ 의 역치손실로도 판단할 수 있거나, 이명에 대한 구술심리검사 와 삶의 질 검사를 통해 이명 단독 발생에 대한 외국(미국, 캐나 다, 호주 등)의 이명의 장애 정도에 따른 보상기준을 참고하여 적용할 수 있다.

이처럼 우리나라의 난청과 이명의 질병 인정 및 판정기준은 몇 가지 문제를 가지고 있다. 첫째로, 타 질병과 달리 장해의 기 준을 근거로 판단하고 있다. 소음성 난청으로서 업무상질병 인 정기준인 $40 \mathrm{~dB}$ 은 청력장해의 최저 장해등급으로 난청 요양 (치료/재활)을 위한 일반적인 난청 질병 진단과 달리 높은 청력 손실을 보이는 중등도 난청 기준임을 알 수 있다. 더구나 이명 은 단독으로 업무상질병으로 다루지 않고 난청을 동반한 이명 으로서 준용장해등급을 적용하고 있다. 둘째로, 공무상/직무상 질병 인정기준이 장애인복지법의 청각장애 판정기준에 근거하 고 있다. 장애인복지법의 기준은 동 장애의 발생 원인을 다투지 않는다는 점에서 난청 발생의 공무상/직무상 근거를 갖는 관련 법과는 대상과 목적이 다름을 알 수 있다. 셋째로, 장해보상 관 점에서만 접근을 하고 있고, 요양 관점의 질환에 대한 치료와 재활 측면(난청 관련 보청기, 이명재훈련 치료 등)이 고려되지 않고 있다. 넷째로, 직업성 난청의 복합적 관련 요인이나 악화 요인에 대한 고려가 필요하고, 다섯째로, 난청 또는 이명 질병 으로 인한 합병증 또는 후유장애(이명으로 인한 불안/우울 등 정신과적 문제 등)에 대해 고려하고 있지 않으며, 여섯째로, 주 관적인 증상의 측면을 고려하지 않은(객관적인 진단의 제한) 진 단으로 이명도 검사 외에 이명장애지수, 구술심리검사, 삶의 질 평가 등이 활용되지 않고 있다. 


\section{질병 인정과 장애 보상의 합리적 기준 마련을 위한 고려사항}

군 복무 관련 난청 또는 이명의 공무상 질병 인정, 장애 보상 의 합리적 기준 마련과 공무상 질병 인정기준의 적용 시 합리 적으로 심사할 수 있는 기반 마련을 위해 동시에 고려하여야 할 부분이 있다.

소음에 장기간 노출되었을 때 청력에 이상을 초래할 수 있는 수준인지 또는 급성 음향외상을 유발할 정도의 충격소음인지 등의 군 병과별 소음 노출 실태의 파악이 우선되어야 한다. 또 한 현역 군인과 전역 군인, 그리고 현역 군인에서도 의무 복무 와 장기 복무 군인(직업 군인)의 난청과 이명의 실태를 파악하 여야 한다. 군인의 (충격)소음에 의한 난청과 이명의 영향은 대 체로 명확하므로 이에 대한 제반 관리대책으로서 소음 노출의 저감과 청력보호를 위한 청력보존프로그램을 실시하여야 한다. 특히, 난청과 이명의 공무 관련성 논란과 관련하여 군 입대 전 과 매년, 그리고 전역 시점에서 난청과 이명의 평가를 위한 시 스템이 구축되어야 한다.

청력보존프로그램은 소음과 관련하여 가장 먼저 시작되었으 며, 더구나 군의 청력보존은 일반 제조업체의 소음 노출 근로자 보다 앞서 시작되었다. 미국의 경우 소음성 난청 및 이명위원회 를 구성하여 제 2 차 세계대전 이래 군 복무 중 각각의 특정 시 기별 청력측정의 규제준수에 의한 데이터 생성 및 생성 데이터 검토, 난청 관련 이용 가능한 데이터의 검토 및 평가, 군 복무 기간 중 잠재적으로 유해한 소음원 파악, 난청과 이명을 유발 할 수 있는 소음 노출 수준 파악, 소음 노출 영향이 추후 발병 으로 이어질 수 있을지의 여부 파악, 소음성 난청의 위험요인 파악, 군인의 청력보호를 위해 청력보호 조처가 적절했던 과거 시기 확인 등의 군 복무와 관련한 소음성 난청 및 이명의 세부 연구를 수행하고 있다.

이명의 평가를 위해서는 이명에 대한 조사, 이명과 가장 연관 성을 보이는 난청에 대한 청각검사, 이명을 객관적 수치로 표현 할 수 있는 정량적 검사로서 이명검사, 이명의 병리적 원인 질병 과의 관련성을 평가하기 위한 의학적 검사 및 이명의 발생과 불 편 정도의 심리적 평가가 필요하다.

우리나라는 입영 시 신체검사로 $0.5 \sim 4 \mathrm{kHz}$ 기도 순음청력검 사를 하고 있고, 2013년부터 입대 1년 후 상병 진급 시 간이청력 기를 이용하여 $1 \mathrm{kHz}$ 기도청력을 측정하고 있어, 군 복무 시 발 생할 수 있는 청력손실과 이명에 관한 평가가 충분히 이루어지 지 않고 있다. 따라서 우리나라도 모든 군인의 청력보존을 위해 입대 전, 매년, 전역 전(또는 전역 후)에 적어도 $0.5 \mathrm{kHz}$ 에서부터 $8 \mathrm{kHz}$ 까지 순음청력검사와 난청 유형 판단을 위한 중이검사, 이명이 있을 경우 이명도 평가와 이명장애를 평가하기 위한 설 문조사(예: THI) 등을 실시하여야 한다. 물론 군 복무 중에 난 청이나 이명이 돌발적(급성)으로 발생하면 그때도 검사를 실시
한다. 특히, $4 \sim 8 \mathrm{kHz}$ 의 고음역 순음청력검사는 소음성 난청을 조기에 평가할 수 있는 좋은 방법으로서, 소음 노출 병력이 짧 은 젊은 대상군에서 중요한 검사이다(Ahmed et al., 2001; Le Prell et al., 2013).

그리고 이명의 공무상 질병의 심사기준 마련 전에 소음, 특히 군의 충격소음의 특성을 감안한 난청의 장애 등급기준과 함께 난청을 동반하지 않은 이명에 대한 판단기준과 장애 평가에 대 한 전반적인 검토가 있어야 한다. 군 복무 중 충격소음의 노출 로 인한 비가역적인 청력손실은 전역 이후의 난청 발생에 기여 하지만, 기 난청자와 이명자로 전역 후 수년이 지나거나 십수 년 이 지난 경우, 또한 과거 군 진료기록이 폐기되어 과거 군 복무 중의 난청과 이명 발생을 직접적으로 증명하지 못한 경우, 과거 군 진료기록이 있다고 하더라도 현재의 난청과 이명과의 관련 성을 규명하지 못하는 경우에 공무 관련성의 판단에 문제가 있 다. 특수한 상황에서 근무하는 군인 등 의무복무자들의 난청 과 이명의 공무 관련성 판단은 국가유공자 등 예우 및 지원에 관한 법률과 연계되기 때문에 근로자를 대상으로 한 업무상 질 병의 산업재해보상보험법의 적용과는 다른 문제가 제기될 수 있다. 국가유공자는 국가유공자 요건을 인정받은 후 상이등급 구분 신체검사에서 7급 이상의 상이등급을 받을 경우, 국가에 서 매월 보상금은 물론 교육, 취업, 의료, 주택 지원 등 각종 지 원이 이루어지기 때문에(산업재해보상보험법의 보상체계와는 다른) 난청과 이명의 공무상 질병의 심사기준과 산업재해보상 보험법에서 소음성 난청의 업무상 질병 인정기준의 단순 비교 만으로는 해결할 수 없는 여러 제반 사항을 고려하여야 한다.

이처럼 군 복무 관련 난청과 이명의 공무상 질병 인정은 사 전에 많은 제도 개선이 이루어지는 것을 전제로 한다. 군인의 난 청과 이명은 다빈도의 상병임에도 불구하고 현역 군인과 제대 군인(전역자), 그리고 현역 군인에서도 의무 복무와 장기 복무 군인(직업 군인)의 난청과 이명의 실태와 관련한 공식적인 통계 자료가 구축되어 있지 못하다. 또한, 전역자의 공상 관련으로 군 진료기록은 보관기관 10 년이 지나면 폐기되므로 이에 대한 과거 난청과 이명을 증빙하는 데 어려움을 겪고 있다.

\section{심사기준의 제안}

군 전역자에서 수많은 난청과 이명자 피해 사례가 문제화되 는 이유로 복무 중에 관심이 없어서, 군의 근무 특수성으로 감 히 문제 제기할 수 있는 환경이 아니어서, 시간이 지나면 나을 것으로 보고, 치료가 불가능하여 포기하거나, 증빙자료(진료기 록 등)가 없다고 해서 전역 후 수년이 지나거나 십수 년이 지난 상태에서 과거에 군 복무 중의 난청과 이명 발생을 직접적으로 증명하지 못한 경우가 태반이다. 그러나 난청과 이명의 실질적 인 공무상 질병 심사 판단에서는 교육훈련 또는 직무 수행 과 
정에서 소음에 노출된 사실이 확인되고 난청 증상이나 난청 소 견이 있는 경우와, 이명은 난청이 있고 현저한 이명이 항상 있는 경우, 그 증상을 타각적 검사에 의한 경우로만 한정하고 있기 때문에 공무상 질병과 국가유공자 요건의 기준과 범위를 충족 하지 못하고 있다. 그러나 군 소음에 의한 난청과 이명의 발생 가능성을 매우 높다고 판단할 때, 군 복무 중 난청과 이명 발생 여부의 입증책임을 군 전역자에게만 일방적으로 지우는 것은 문제의 소지가 있다. 즉, 국가의 군인의 의무기록 관리뿐 아니 라 앞서 논의한 군 소음에 대한 제반 노출 실태와 소음으로 인 한 군인의 청력 변화 상태 등의 관리 책임이 있기 때문이다.

미국, 캐나다, 호주 등 외국은 이명의 장애 보상과 관련한 장 애율은 낮지만(10\% 내외), 난청과는 별개로 이명에 대한 심리 학적 평가와 삶의 질 평가 등을 이용하여 인정하고 있다. 우리 나라는 한 귀 이상에서 $50 \mathrm{~dB}$ 의 난청 장애를 동반하여야만 이 명에 대해 준용등급이 적용되기 때문에 이명의 단독 보상은 불 가능하다. 우리나라의 경우 난청 장애의 등급 결정을 위한 평 균청력 산정방법 및 상이등급의 구분과 최저 등급의 청력손실 기준이 관련 법에 따라 다르다. 이명의 단독 장애는 보상 적용 대상이 되지 않고 난청을 동반하여야만 인정을 하고 있으며, 더 구나 요구되는 난청의 정도는 $50 \mathrm{~dB}$ 의 중도 난청 이상이어야 한다. 우리나라의 난청과 이명 장애 관련 법은 난청 장애 고정 시의 보상에 한하며, 이명의 진단과 평가, 그리고 이명으로 인 한 청각학적 문제뿐 아니라 이로 인한 정신심리적 영향과 삶의 질과 관련한 치료 및 재활 측면이 고려되지 못하고 있다.

군 전역자의 이명 장애는 $3 \sim 6 \mathrm{kHz}$ 또는 $8 \mathrm{kHz}$ 의 고음역에서 의 역치손실이 큰 초기의 소음성 난청이나 정상 청력 범위를 보 이는 경우가 많다. 군에서의 이명은 난청을 호소하지 않고 단독 으로 발생할 수 있으며, 난청을 동반하더라도 저/중음역대의 역 치 손실은 크지 않고 고음역의 난청으로 $3 \sim 6 \mathrm{kHz}$ 내지 $8 \mathrm{kHz}$ 에서의 역치가 상승되어 나타나므로, 평균역치로 산정하여 50 $\mathrm{dB}$ 이상의 중등도 난청 장애를 동반한 이명으로 준용등급을 적용, 결정 시에는 대부분 제외될 수밖에 없다. 따라서 군 복무 중 발생한 이명은 난청을 동반한 경우뿐 아니라 난청을 동반하 지 않은 단독 이명이라도 상이계열의 귀(내이 등)의 청력상이에 이명을 포함하고(별표 2), 준용등급에 이명을 적용(별표 4)하여 요양과 장해 보상에 이명 상이기준을 마련하여야 한다.

본 저자는 군 전역자의 공무상 질병으로서의 이명을 1) 군 복무기간 중 소음에 노출되어 난청을 동반한 이명이 발생한 경 우, 2) 다만, 난청이 없이 이명만 있는 경우에는 발생 후 치료의 필요성이 있다고 의학적으로 판단되거나 인정되는 경우로 가) 평균청력역치는 정상이나 고음역(특히, $3 \sim 8 \mathrm{kHz}$ )에서 청력역치 손실이 뚜렷할 것, 나) 이명도 검사로 이명이 확인될 것, 다) 이명 이 항상 들릴 것, 라) 일상생활에도 심대한 지장을 줄 정도일 것
을 제안하고자 한다. 일상생활의 제한에 대해서는 이명에 대한 심리학적 평가와 삶의 질 평가방법, 즉 이명이 삶에 미치는 영 향을 알아보는 신뢰도와 타당도가 검증된 기 개발된 이명 설문 도구를 활용하여 고도 또는 심도의 이명장애군에 대해 적용할 수 있을 것이다.

그리고 이명의 치료를 위해서는 이명의 발생 원인을 파악하 고, 정확한 이명의 진단과 이명의 동반 증상이나 질환, 이명으 로 인한 장애를 평가하기 위해 청각학적 검사와 이명검사, 이명 의 병리적 원인 질병과의 관련성을 평가하기 위한 의학적 검사 및 이명의 발생과 불편 정도의 심리적 평가를 통한 이명의 평가 와 이의 치료/재활을 위한 여러 전문 분야(청각학, 이비인후과 학, 물리치료, 신경학, 심리상담, 심리학, 정신의학 등)의 다각적 인 접근이 요구된다. 이명에 대한 치료와 재활은 전문가의 이명 평가와 이명자 개인의 선호에 따라 청각학적인 방법(MP3 player, sound generator, 보청기, 인공와우 등)과 정신·심리적 인 방법(심리상담, 정신과적 치료 등)으로 접근할 수 있다. 환자 일지를 통한 문제 파악과 치료방법에 따른 반응을 통해 적절한 재활방법을 모색하고, 정서적인 요구는 심층상담을 통해 지원 하고 이과적 손상이 병합된 경우에는 그에 따른 복합적인 의학 적·청각학적 해결을 요한다(Searchfield \& Baguley, 2011). 따 라서 군인의 이명은 다빈도의 질환인 만큼 군에서의 (충격)소 음에 의한 이명의 진단과 치료를 위해서는 이 질환만을 전문으 로 하는 기관의 설립도 요구된다.

이를 통해 군인의 이명 피해에 대해 조기에 전문적인 진단과 이후 실효적인 치료와 재활 및 장애에 대한 적정한 보상체계를 마련할 수 있을 것이다.

\section{CONCLUSION}

군 복무자는 충격소음에 상시 노출되어 일반 인구집단에 비 해 높은 청력역치를 보이며, 이명을 동반하는 경우가 많다. 군 에서의 이명은 난청을 호소하지 않고 단독으로 발생할 수 있으 며, 난청을 동반하더라도 저/중음역대의 역치 손실은 크지 않 고 $3 \sim 6 \mathrm{kHz}$ 내지 $8 \mathrm{kHz}$ 의 고음역에서의 청력역치가 상승되어 나타날 수 있다. 따라서 평균역치로 산정하여 $50 \mathrm{~dB}$ 이상의 중 등도 난청 장애를 동반한 이명에 한해 준용등급을 장해 평가 에 적용할 경우 대부분 보상에서 제외될 수밖에 없다. 또한 이 명의 진단과 평가, 그리고 이명으로 인한 청각학적 문제뿐 아니 라 이로 인한 정신 심리적 영향과 삶의 질과 관련한 치료 및 재 활 측면이 고려되지 못하고 있다. 이 연구는 군 소음으로 인한 이명 장애의 특성을 살펴보고, 특히 전역 군인의 이명에 대한 공무상 질병 인정과 장해 보상의 기준 적용과 심사에 따르는 제반 문제에 대해 고찰하고 제언하고자 하였다. 
중심 단어 : 이명·군·소음·난청·장해.

\section{REFERENCES}

Ahmed, H. O., Dennis, J. H., Badran, O., Ismail, M., Ballal, S. G., Ashoor, A., et al. (2001). High-frequency $(10-18 \mathrm{kHz})$ hearing thresholds: Reliability, and effects of age and occupational noise exposure. Occupational Medicine, 51(4), 245-258.

Axelsson, A. \& Ringdahl, A. (1989). Tinnitus--a study of its prevalence and characteristics. British Journal of Audiology, 23(1), 53-62.

Barnea, G., Attias, J., Gold, S., \& Shahar, A. (1990). Tinnitus with normal hearing sensitivity: Extended high-frequency audiometry and auditory-nerve brain-stem-evoked responses. Audiology, 29(1), 36-45.

Erlandsson, S. I. \& Hallberg, L. R. (2000). Prediction of quality of life in patients with tinnitus. British Journal of Audiology, 34(1), 11-19.

Erlandsson, S. I., Rubinstein, B., Axelsson, A., \& Carlsson, S. G. (1991). Psychological dimensions in patients with disabling tinnitus and craniomandibular disorders. British Journal of Audiology, 25(1), 15-24.

Guest, H., Munro, K. J., Prendergast, G., Howe, S., \& Plack, C. J. (2017). Tinnitus with a normal audiogram: Relation to noise exposure but no evidence for cochlear synaptopathy. Hearing Research, 344, 265-274.

Hallam, R. S. (1996). Manual of the Tinnitus Questionnaire (TQ). London: The Psychological Corporation.

Humes, L. E., Joellenbeck, L. M., \& Durch, J. S. (2006). Noise and Military Service: Implications for Hearing Loss and Tinnitus. Washington, DC: The National Academies Press.

Kim, D. Y., Kim, K. S., \& Bahng, J. (2012a). Factors affecting tinnitus handicap in discharged soldiers with tinnitus. Audiology, 8(2), 149-157.

Kim, J. H., Lee, S. Y., Kim, C. H., Lim, S. L., Shin, J. N., Chung, W. H., et al. (2002). Reliability and validity of a Korean adaptation of the Tinnitus Handicap Inventory. Korean Journal of Otolaryngology-Head and Neck Surgery, 45(4), 328-334.

Kim, K. S., \& Chung, H. K. (2003). The effect of working noise exposure and military background on the hearing threshold. Korean Journal of Preventive Medicine, 36(2), 137-146.

Kim, K. S., Kim, J. H., \& Yoon, Y. H. (2012b). The characterisitics of tinnitus and its relationship to depression from tinnitus acquired from military service. Korean Journal of Otorhinolaryngology-Head and Neck Surgery, 55(12), 757-763.

Kujawa, S. G. \& Liberman, M. C. (2009). Adding insult to injury: Cochlear nerve degeneration after "temporary" noise-induced hearing loss. Journal of Neuroscience, 29(45), 14077-14085.

Kuk, F. K., Tyler, R. S., Russell, D., \& Jordan, H. (1990). The psychometric properties of a tinnitus handicap questionnaire. Ear and Hearing, 11(6), 434-445.

Lee, J. E., Kim, K. S., \& Bahng, J. (2014). The relationship of tinnitus handicap and health status measured by SF-36 in discharged soldiers. Audiology, 10(3), 208-222.

Le Prell, C. G., Spankovich, C., Lobariñas, E., \& Griffiths, S. K. (2013). Extended high-frequency thresholds in college students: Effects of music player use and other recreational noise. Journal of the American Acade- my of Audiology, 24(8), 725-739.

Moon, S. (2007). Noise-induced hearing loss caused by gunshot in South Korean military service. Military Medicine, 172(4), 421-425.

Moon, I. S., Choi, H. S., Kim, H., Kim, J., \& Lee, W. S. (2008). Clinical characteristics of acoustic trauma caused by rifle gunshot noise. Korean Journal of Otorhinolaryngology-Head and Neck Surgery, 51(8), 699-704.

Newman, C. W., Jacobson, G. P., \& Spitzer, J. B. (1996). Development of the tinnitus handicap inventory. Archives of Otolaryngology-Head and Neck Surgery, 122(2), 143-148.

Odess, J. S. (1972). Acoustic trauma of sportsman hunter due to gun firing. The Laryngoscope, 82(11), 1971-1989.

Samarei, R. \& Fatholahi, N. (2014). Causes of tinnitus in patients referred to ENT clinic of Imam Khomeini hospital in Urmia, 2012-2013. Global Journal of Health Science, 6(7 Spec No), 136-143.

Salmivalli, A. (1978). Military audiological aspects in noise-induced hearing losses. Acta Oto-Laryngologica, 86(Supp360), 96-97.

Sanchez, T. G., Medeiros, Í. R. T. D., Levy, C. P. D., Ramalho, J. D. R. O., \& Bento, R. F. (2005). Tinnitus in normally hearing patients: Clinical aspects and repercussions. Revista Brasileira de Otorrinolaringologia, 71(4), 427-431.

Savolainen, S. \& Lehtomäki, K. M. (1997). Impulse noise and acute acoustic trauma in Finnish conscripts number of shots fired and safe distances. Scandinavian Audiology, 26(2), 122-126.

Searchfield, G. D. \& Baguley, D. M. (2011). The role of the audiologist in tinnitus practice. In A. R. Møller, B. Langguth, D. DeRidder, \& T. Kleinjung. Textbook of Tinnitus (pp. 215-222). New York, NY: Springer.

Shim, H. J., Kim, S. K., Park, C. H., Lee, S. H., Yoon, S. W., Ki, A. R., et al. (2009). Hearing abilities at ultra-high frequency in patients with tinnitus. Clinical and Experimental Otorhinolaryngology, 2(4), 169-174.

Tyler, R. S. \& Baker, L. J. (1983). Difficulties experienced by tinnitus sufferers. Journal of Speech and Hearing Disorders, 48(2), 150-154.

U.S. Army Center for Health Promotion and Preventive Medicine. (2004). DOEHRS Data Repository: Army Hearing Conservation Program Compliance Reports, 1988-2003. Data provided to the Institute of Medicine Committee on Noise-Induced Hearing Loss and Tinnitus Associated with Military Service from World War II to the Present, Washington, DC.

Xu, X., Bu, X., Zhou, L., Xing, G., Liu, C., \& Wang, D. (2011). An epidemiologic study of tinnitus in a population in Jiangsu Province, China. Journal of the American Academy of Audiology, 22(9), 578-585.

Ylikoski, J. (1989). Acute acoustic trauma in Finnish conscripts. Etiological factors and characteristics of hearing impairment. Scandinavian Audiology, 18(3), 161-165.

Ylikoski, J., Juntunen, J., Matikainen, E., Ylikoski, M., \& Ojala, M. (1988). Subclinical vestibular pathology in patients with noise-induced hearing loss from intense impulse noise. Acta Oto-Laryngologica, 105(5-6), 558-563.

Ylikoski, M. E. \& Ylikoski, J. S. (1994). Hearing loss and handicap of professional soldiers exposed to gunfire noise. Scandinavian Journal of Work, Environment and Health, 20(2), 93-100. 